\title{
Gambaran Kadar Asam Urat Pada Pekerja Bengkel Las di Kecamatan Sukarami Palembang Tahun 2019
}

\author{
Asrori, Nurhayati, Abdul Mutholib, Tiara Fita Ellinasari \\ Jurusan Analis Kesehatan Poltekes Kemenkes Palembang
}

\begin{abstract}
Abstrak
Pekerja bengkel las berpotensi menghirup asap yang mengandung kadmium dari proses pengelasan, hal ini dapat menyebabkan disfungsi ginjal, yang menghambat ekskresi urat dan dapat menyebabkan hiperurisemia. Penelitian ini bertujuan mengetahui gambaran kadar asam urat pada pekerja bengkel las di Kecamatan Sukarami Palembang. Penelitian ini bersifat deskriptif observasional. Sampel sebanyak 40 pekerja bengkel las. Kadar asam urat diperiksa dengan metode uricase. Hasil penelitian ini mendapatkan 6 orang $(15,0 \%)$ dengan kadar asam urat tinggi dan 34 orang $(85,0 \%)$ dengan kadar asam urat normal. Dari 6 sampel dengan kadar asam urat tinggi; berdasarkan umur, sebanyak 3 orang $(50,0 \%)$ dengan umur berisiko dan 3 orang $(8,8 \%)$ dengan umur tidak berisiko; berdasarkan waktu kerja, sebanyak 1 orang $(25,0 \%)$ dengan waktu kerja berisiko dan 5 orang $(13,9 \%)$ dengan waktu kerja tidak berisiko; berdasarkan masa kerja, sebanyak 4 orang $(40,0 \%)$ dengan masa kerja berisiko dan 2 orang $(6,7 \%)$ dengan masa kerja tidak berisiko; berdasarkan penggunaan APD sebanyak 5 orang $(23,8 \%)$ dengan penggunaan APD tidak sesuai dan 1 orang $(5,3 \%)$ dengan penggunaan APD sesuai; berdasarkan tekanan darah, sebanyak 1 orang $(14,3 \%)$ dengan tekanan darah tinggi, 4 orang $(15,4 \%)$ dengan tekanan darah normal dan 1 orang $(14,3 \%)$ dengan tekanan darah rendah; berdasarkan asupan purin, sebanyak 3 orang $(25,0 \%)$ dengan asupan purin tinggi dan 3 orang $(13,6 \%)$ dengan asupan purin sedang.
\end{abstract}

Kata Kunci : asam urat, kadmium, pekerja las, tekanan darah, purin

\section{Description of Uric Acid Levels in Las Workshop Workers in Sukarami District, Palembang, 2019}

\begin{abstract}
Welders are highly potential to be exposed to cadmium from welding process, this can cause kidney dysfunction, which inhibits urinary excretion and can cause hyperuricemia. This study aims to determine the uric acid levels in welders at Sukarami District Palembang. This This study was descriptive observational. The subject of this study was 40 welding workers. The method used to determine uric acid level was uricase. The results of this study found 6 people $(15.0 \%)$ people with high uric acid level and $34(85.0 \%)$ people with normal uric acid level. From 6 subjects with high uric acid levels, based on age, $3(50.0 \%)$ people were in risky age and $3(8.8 \%)$ people were in non-risky age; based on working time, $1(25.0 \%)$ person were in risky working time and 5 $(13.9 \%)$ people were in non-risky working time; based on length of work, $4(40.0 \%)$ people were in risky length of work and $2(6.7 \%)$ people were in non-risky length of work; based on the use of PPE, $5(23.8 \%)$ people wore complete PPE and 1 (5.3\%) person wore incomplete PPE; based on blood pressure, 1 (14.3\%) person had high blood pressure, 4 (15.4\%) people had normal blood pressure, and 1 (14.3\%) person had low blood pressure; based on purine intake, $3(25.0 \%)$ people had high purine intake and $3(13.6 \%)$ people had moderate purine intake. It is recommended for welders to use complete PPE in order to reduce the exposure to cadmium from welding process.
\end{abstract}

Keywords : uric acid, cadmium, welding workers, blood pressure, purines

Korespondensi: Asrori, Jurusan Analis Kesehatan Politeknik Kesehatan Kemenkes Palembang, Jl. Jend. Sudirman KM.3.5 No. 1365 Komplek Rs. Moh. Hoesin ; Sumatera Selatan. Palembang 30126, e-mail asrori123@poltekkespalembang.ac.id 


\section{Pendahuluan}

Setiap pekerjaan selalu memiliki risiko terjadinya kecelakaan kerja. Potensi terjadinya kecelakaan tersebut tergantung dari jenis produksi, teknologi yang dipakai, bahan yang digunakan, tata ruang dan lingkungan bangunan serta kualitas manajemen dan tenaga pelaksana. Masalah Keselamatan dan Kesehatan Kerja (K3) di Indonesia masih sering terabaikan yang menyebabkan masih tingginya angka kecelakaan akibat kerja (RI, 2015).

Dengan semakin berkembangnya industrialisasi dan teknologi yang banyak menggunakan unsur logam sebagai bahan baku, semakin banyak juga risiko terjadinya pencemaran lingkungan dan gangguan kesehatan baik pada manusia, hewan ataupun tanaman. Selain itu, pekerja yang bekerja menggunakan logam atau memproduksi logam juga sangat berisiko terjadinya gangguan kesehatan akibat logam tersebut (Indonesia, 2012).

Pekerja yang memiliki frekuensi cukup besar dalam terpajan logam berat, diantaranya pekerja pada produksi makanan/minuman kaleng, produksi barang elektronik, pembuatan kembang api, pembuatan aluminium foil (pembungkus makanan), produksi otomotif, pekerja bengkel mobil dan motor, pekerja pada perakitan pesawat terbang, pekerja pembuat uang logam, pekerja pembuat kabel, pekerja industri bahan bakar, tukang cat semprot, pekerja industri baterai, pekerja penyepuhan, pekerja industri keramik, dan pekerja bengkel las (Indonesia, 2012).

Pekerja bengkel las merupakan pekerja yang bekerja dengan melibatkan pemanasan dua logam dengan suhu tinggi. Panas dan energi yang merupakan hasil dari proses pengelasan akan menyebabkan terjadinya berbagai reaksi kimia dan fisika. Reaksi-reaksi ini akan menghasilkan beberapa zat kimia yang bersifat toksik baik yang berbentuk fume, debu atau uap dan radiasi elektromagnetik (nonionizing radiation). Potensi pekerja bengkel las untuk terpapar logam sangatlah tinggi melalui fumes (asap las) yang terhirup pada saat proses pengelasan (Fitriadi, 2009).

Pengelasan dapat menghasilkan uap dan gas berbahaya bagi kesehatan, terutama jika terhirup atau tertelan oleh tukang las. Asap adalah partikel padat yang berasal dari bahan habis pakai las, logam dasar, dan lapisan apapun yang ada pada logam dasar. Asap pengelasan yang dihasilkan selama proses pengelasan meliputi paling sedikit 14 logam, terdiri dari mangan (Mn), berilium (Be), kadmium (Cd), kromium (Cr), kobalt (Co), tembaga $(\mathrm{Cu})$, besi $(\mathrm{Fe})$, timbal $(\mathrm{Pb})$, merkuri (Hg), molibdenum (Mo), nikel (Ni), zink ( $\mathrm{Zn})$, antimon (Sb), dan vanadium (V) (Hashmi, 2014).

Kadmium merupakan logam berat yang berbentuk agak lunak, berwarna metal biruputih yang hampir sama dengan dua jenis logam stabil lainnya yaitu seng dan merkuri. Kadmium dipergunakan sebagai bahan pelapis besi dan baja, pembuatan baterai, electroplating, pembelahan nuklir (nuclear fission), cat, pigmen warna, pensil warna, dan heliumkadmium laser. Kadmium relatif mudah terbakar sehingga mmbentuk asap kadmium oksida. Kadmium mengeluarkan gas racun yang cukup tinggi (Sembel, 2015).

Keracunan akut kadmium dapat menyebabkan gangguan saluran cerna (setelah tertelan makanan yang telah terpapar kadmium), asma kimiawi (setelah inhalasi asap kadmium oksida), bronkitis, pneumonitis, gagal ginjal akut, dan gangguan fungsi hati. Keracunan kronik kadmium melalui pernapasan menyebabkan aminoasiduria, glikosuria, hiperkalsiuria, fosfaturia, proteinuria, peningkatan kreatinin plasma, nefrolitiasis, anemia, penyakit itai-itai, dan gangguan ekskresi asam. Berdasarkan penelitian Mutiara Suci Imron tahun 2017 terdapat 15,2\% pekerja bengkel las yang memiliki hasil proteinuria positif (Imron, 2017)

$\begin{array}{llr}\text { Menghirup debu } & \text { kadmium } & \text { dapat } \\ \text { menyebabkan gangguan } & \text { pada } & \text { saluran } \\ \text { pernafasan dan masalah } & \text { ginjal. } & \text { Ginjal }\end{array}$ pernafasan dan masalah ginjal. Ginjal
kehilangan fungsinya untuk menghilangkan asam dari darah dalam disfungsi tubulus ginjal proksimal. Keracunan kadmium sub-kronis dapat menyebabkan sekresi urat menurun dari sel tubular. Toksisitas kadmium dapat menyebabkan gangguan ekskresi paminohippurate akibat hilangnya pembawa anion organik di membran basolateral tubulus proksimal. Hal inilah yang menyebabkan kerusakan ginjal awal akibat paparan kadmium dapat menyebabkan kerusakan ekskresi urat dan menimbulkan hiperurisemia (Sun et al., 2017). Selain itu, menurut penelitian Agneta Akesson tahun 2014 menunjukkan bahwa proteinuria sebagai efek buruk paparan kadmium dikarenakan disfungsi tubulus ginjal (Åkesson et al., 2014).

Hiperurisemia merupakan keadaan yang terjadi ketika kadar asam urat di dalam darah tinggi. Hal ini terjadi karena adanya peningkatan produksi asam urat dalam 
metabolisme atau penurunan ekskresi (pengeluaran) asam urat dari dalam tubuh melalui ginjal dalam bentuk urine (Damayanti, 2012)

Pada suatu pekerjaan bisa dipengaruhi oleh beberapa faktor, diantaranya adalah umur. Umur digunakan agar dapat memberikan gambaran tentang faktor penyebab penyakit tersebut. Umur pekerja sangat diperhatikan karena dapat mempengaruhi fisik, mental, kemampuan kerja dan tanggung jawab pekerja (Putri \& Setiawina, 2013).

Selain umur, faktor lain yang dapat mempengaruhi pekerja bengkel las adalah waktu kerja. Seorang pekerja tidak mampu dibebani lebih dari $30 \%$ dari tenaga maksimumnya selama 8 jam sehari. Oleh karena itu, waktu kerja dikategorikan menjadi dua, yaitu berisiko (>8 jam) dan tidak berisiko ( $\$ 8$ jam).(14) Dilihat berdasarkan waktu paruh kadmium dalam tubuh, seseorang yang telah terpapar selama 10 tahun atau lebih akan terkena efek toksisitas kadmium (Winata, 2017).

Menurut penelitian di Manado tahun 2014, terdapat $50 \%$ pekerja pengelasan yang memiliki tindakan baik terhadap penggunaan alat pelindung diri (Rorimpandey, 2014). Menurut penelitian di Kalimantan Selatan tahun 2016 , terdapat $75 \%$ pekerja pengelasan yang tidak menggunakan alat pelindung diri saat bekerja (Permatasari et al., 2017)

Selain itu paparan asap kadmium yang merusak tubulus ginjal proksimal dapat menyebabkan penurunan proses sekresi di tubulus ginjal. Kristal asam urat yang menumpuk dikarenakan penurunan proses sekresi di tubulus ginjal menyebabkan kristal asam urat akan tertekan dan menusuk dinding pembuluh darah yang menghambat aliran darah dan menyebabkan peningkatan tekanan darah (Utami \& Lentera, 2005).

Penelitian Sun dkk tahun 2017 tentang Cadmium Exposure and Its Association with Serum Uric Acid and Hyperuricemia terhadap 2996 responden di Cina, didapatkan hasil bahwa pria dengan tingkat median Cadmium Blood (CdB) sebesar $2.40 \mu \mathrm{g} / \mathrm{L}$ lebih berisiko terkena hiperurisemia dibandingkan dengan pria dengan tingkat median $\mathrm{CdB}$ di bawah 2.40 $\mu \mathrm{g} / \mathrm{L}$. Selain itu, penderita hipertensi dengan persentase sebesar 47,8\% lebih berisiko terkena hiperurisemia (Sun et al., 2017).

Faktor lain yang dapat mempengaruhi kadar asam urat dalam darah adalah riwayat asupan purin. Hal ini disebabkan karena kadar asam urat dalam darah dapat dipengaruhi oleh asupan purin tinggi yang didapat dari makanan. Apabila seseorang mengkonsumsi makanan yang mengandung purin, maka purin akan langsung dikatabolisme oleh usus (Damayanti, 2012).

Salah satu kecamatan yang termasuk ke dalam wilayah dengan populasi terbesar di Kota Palembang adalah Kecamatan Sukarami. Berdasarkan data Badan Pusat Statistik Kota Palembang tahun 2016, Kecamatan Sukarami merupakan kecamatan dengan jumlah penduduk terbesar ke-3 di Kota Palembang. Berdasarkan observasi yang telah dilakukan, di Kecamatan Sukarami terdapat sekitar 80 bengkel las.

Tujuan penelitian ini adalah untuk mengetahui gambaran kadar asam urat pada pekerja bengkel las di Kecamatan Sukarami Palembang tahun 2019.

\section{Metode}

Penelitian ini merupakan penelitian deskriptif observasional dengan pendekatan Cross Sectional. Pengambilan sampel dilakukan di bengkel las yang terdapat di Kecamatan Sukarami Palembang. Pemeriksaan kadar asam urat dilakukan di Balai Besar Laboratorium Kesehatan (BBLK) Palembang. Penelitian dilaksanakan pada 9 - 14 Agustus 2019.

Populasi dalam penelitian ini adalah pekerja bengkel las di Kecamatan Sukarami Palembang. Total populasi adalah 162 orang. Sampel penelitian ini sebanyak 40 orang. Teknik pengambilan sampel adalah cluster sampling. Metode pemeriksaan adalah metode Uricase/Enzimatik Trinde. Hasil kadar asam urat akan diolah dengan menggunakan Analisis univariat dan bivariat berdasarkan umur, waktu kerja, masa kerja, penggunaan alat pelindung diri, tekanan darah, dan asupan purin.

\section{Hasil}

Tabel 1. Distribusi Statistik Kadar Asam Urat pada Pekerja Bengkel Las

\begin{tabular}{ccccc}
\hline Variabel & N & Rerata & SD & $\begin{array}{c}\text { Min- } \\
\text { Maks }\end{array}$ \\
\hline $\begin{array}{ccccc}\text { Kadar } \\
\text { Asam } \\
\text { Urat }\end{array}$ & 40 & 5,8828 & 1,05731 & $\begin{array}{c}3,53- \\
7,74\end{array}$ \\
\hline
\end{tabular}

Berdasarkan tabel 1 diketahui bahwa dari 40 pekerja bengkel las didapatkan rata-rata kadar asam urat pada pekerja bengkel las yaitu $5,88 \mathrm{mg} / \mathrm{dL}$ dengan standar deviasi (SD) 1,05731. Kadar asam urat terendah yaitu 3,53 
$\mathrm{mg} / \mathrm{dL}$ dan kadar asam urat tertinggi yaitu 7,74 $\mathrm{mg} / \mathrm{dL}$.

Tabel 2. Distribusi Frekuensi Kadar Asam Urat pada Pekerja Bengkel Las

\begin{tabular}{lcc}
\hline \multicolumn{1}{c}{ Kategori } & Frekuensi & Persentase (\%) \\
\hline Tinggi & 6 & 15,0 \\
Normal & 34 & 85,0 \\
\hline Total & 40 & 100,0 \\
\hline
\end{tabular}

Berdasarkan tabel 2 dapat diketahui bahwa dari 40 pekerja bengkel las yang diperiksa didapat hasil sebanyak 6 orang $(15,0 \%)$ dengan hasil kadar asam urat tinggi dan 34 orang $(85,0 \%)$ dengan hasil kadar asam urat normal.

Tabel 3. Distribusi Frekuensi Kadar Asam Urat pada Pekerja Bengkel Las Berdasarkan Umur

\begin{tabular}{|c|c|c|c|c|c|c|}
\hline \multirow{3}{*}{ Umur } & \multicolumn{4}{|c|}{ Kadar Asam Urat } & \multirow{2}{*}{\multicolumn{2}{|c|}{ Total }} \\
\hline & \multicolumn{2}{|c|}{ Tinggi } & \multicolumn{2}{|c|}{ Normal } & & \\
\hline & $\mathbf{N}$ & $\%$ & $\mathbf{n}$ & $\%$ & $\mathbf{N}$ & $\%$ \\
\hline $\begin{array}{c}\text { Berisiko } \\
\text { (>40 Tahun) }\end{array}$ & 3 & 50,0 & 3 & 50,0 & 6 & 100,0 \\
\hline $\begin{array}{c}\text { Tidak } \\
\text { Berisiko } \\
\text { ( } \$ 40 \text { Tahun) }\end{array}$ & 3 & 8,8 & 31 & 91,2 & 34 & 100,0 \\
\hline Total & 6 & 15,0 & 34 & 85,0 & 40 & 100,0 \\
\hline
\end{tabular}

Berdasarkan tabel 3 didapatkan hasil dari 6 orang yang memiliki umur berisiko ( $>40$ tahun), sebanyak 3 orang $(50,0 \%)$ dengan hasil kadar asam urat tinggi dan 3 orang $(50,0 \%)$ dengan hasil kadar asam urat normal. Sedangkan dari 34 orang yang memiliki umur tidak berisiko ( $\$ 40$ tahun), sebanyak 3 orang $(8,8 \%)$ dengan hasil kadar asam urat tinggi dan 31 orang $(91,2 \%)$ dengan hasil kadar asam urat normal.

Tabel 4. Distribusi Frekuensi Kadar Asam Urat pada Pekerja Bengkel Las Berdasarkan Waktu Kerja

\begin{tabular}{|c|c|c|c|c|c|c|}
\hline \multirow{3}{*}{$\begin{array}{l}\text { Waktu } \\
\text { Kerja }\end{array}$} & \multicolumn{4}{|c|}{ Kadar Asam Urat } & \multirow{2}{*}{\multicolumn{2}{|c|}{ Total }} \\
\hline & \multicolumn{2}{|c|}{ Tinggi } & \multicolumn{2}{|c|}{ Normal } & & \\
\hline & $\mathrm{n}$ & $\%$ & $\mathbf{n}$ & $\%$ & $\mathbf{N}$ & $\%$ \\
\hline $\begin{array}{l}\text { Berisiko } \\
\text { (>8 Jam) }\end{array}$ & 1 & 25,0 & 3 & 75,0 & 4 & 100,0 \\
\hline $\begin{array}{c}\text { Tidak } \\
\text { Berisiko } \\
(\$ 8 \mathrm{Jam})\end{array}$ & 5 & 13,9 & 31 & 86,1 & 36 & 100,0 \\
\hline Total & 6 & 15,0 & 34 & 85,0 & 40 & 100,0 \\
\hline
\end{tabular}

Berdasarkan tabel 4 didapatkan hasil dari 4 orang yang memiliki waktu kerja berisiko ( $>8$ jam), sebanyak 1 orang $(25,0 \%)$ dengan hasil kadar asam urat tinggi dan 3 orang $(75,0 \%)$ dengan hasil kadar asam urat normal. Sedangkan dari 36 orang yang memiliki waktu kerja tidak berisiko ( $\$ 8 \mathrm{jam}$ ), sebanyak 5 orang $(13,9 \%)$ dengan hasil kadar asam urat tinggi dan 31 orang $(86,1 \%)$ dengan hasil kadar asam urat normal.

Tabel 5. Distribusi Frekuensi Kadar Asam Urat pada Pekerja Bengkel Las Berdasarkan Masa Kerja

\begin{tabular}{|c|c|c|c|c|c|c|}
\hline \multirow{3}{*}{ Masa Kerja } & \multicolumn{4}{|c|}{ Kadar Asam Urat } & \multirow{2}{*}{\multicolumn{2}{|c|}{ Total }} \\
\hline & \multicolumn{2}{|c|}{ Tinggi } & \multicolumn{2}{|c|}{ Normal } & & \\
\hline & $\mathbf{n}$ & $\%$ & $\mathbf{n}$ & $\%$ & $\mathbf{N}$ & $\%$ \\
\hline $\begin{array}{c}\text { Berisiko } \\
\text { ( } \geq 10 \text { Tahun) }\end{array}$ & 4 & 40,0 & 6 & 60,0 & 10 & 100,0 \\
\hline $\begin{array}{c}\text { Tidak } \\
\text { Berisiko } \\
\text { (<10 Tahun) }\end{array}$ & 2 & 6,7 & 28 & 93,3 & 30 & 100,0 \\
\hline Total & 6 & 15,0 & 34 & 85,0 & 40 & 100,0 \\
\hline
\end{tabular}

Berdasarkan tabel 5 didapatkan hasil dari 10 orang yang memiliki masa kerja berisiko ( $\geq 10$ tahun), sebanyak 4 orang $(40,0 \%)$ dengan hasil kadar asam urat tinggi dan 6 orang $(60,0 \%)$ dengan hasil kadar asam urat normal. Sedangkan dari 36 orang yang memiliki masa kerja tidak berisiko ( $<10$ tahun), sebanyak 2 orang $(6,7 \%)$ dengan hasil kadar asam urat tinggi dan 28 orang $(93,3 \%)$ dengan hasil kadar asam urat normal.

Tabel 6. Distribusi Frekuensi Kadar Asam Urat pada Pekerja Bengkel Las Berdasarkan Alat Pelindung Diri

\begin{tabular}{|c|c|c|c|c|c|c|}
\hline \multirow{3}{*}{$\begin{array}{c}\text { Alat } \\
\text { Pelindung } \\
\text { Diri (APD) }\end{array}$} & \multicolumn{4}{|c|}{ Kadar Asam Urat } & \multirow{2}{*}{\multicolumn{2}{|c|}{ Total }} \\
\hline & \multicolumn{2}{|c|}{ Tinggi } & \multicolumn{2}{|c|}{ Normal } & & \\
\hline & $\mathbf{N}$ & $\%$ & $\mathbf{n}$ & $\%$ & $\mathbf{N}$ & $\%$ \\
\hline $\begin{array}{l}\text { Tidak } \\
\text { Sesuai }\end{array}$ & 5 & 23,8 & 16 & 76,2 & 21 & 100,0 \\
\hline Sesuai & 1 & 5,3 & 18 & 94,7 & 19 & 100,0 \\
\hline Total & 6 & 15,0 & 34 & 85,0 & 40 & 100,0 \\
\hline
\end{tabular}

Berdasarkan tabel 6 didapatkan hasil dari 21 orang yang tidak sesuai dalam penggunaan APD, sebanyak 5 orang $(23,8 \%)$ dengan hasil kadar asam urat tinggi dan 16 orang $(60,0 \%)$ dengan hasil kadar asam urat normal. Sedangkan dari 19 orang yang sesuai dalam penggunaan APD, sebanyak 1 orang $(5,3 \%)$ dengan hasil kadar asam urat tinggi dan 18 orang $(94,7 \%)$ dengan hasil kadar asam urat normal. 
Tabel 7. Distribusi Frekuensi Kadar Asam Urat pada Pekerja Bengkel Las

Berdasarkan Tekanan Darah

\begin{tabular}{|c|c|c|c|c|c|c|}
\hline \multirow{3}{*}{$\begin{array}{c}\text { Tekanan } \\
\text { Darah }\end{array}$} & \multicolumn{4}{|c|}{ Kadar Asam Urat } & \multirow{2}{*}{\multicolumn{2}{|c|}{ Total }} \\
\hline & \multicolumn{2}{|c|}{ Tinggi } & \multicolumn{2}{|c|}{ Normal } & & \\
\hline & $\mathbf{N}$ & $\%$ & $\mathbf{n}$ & $\%$ & $\mathbf{N}$ & $\%$ \\
\hline Tinggi & 1 & 14,3 & 6 & 85,7 & 7 & 100,0 \\
\hline Normal & 4 & 15,4 & 22 & 84,6 & 26 & 100,0 \\
\hline Rendah & 1 & 14,3 & 6 & 85,7 & 7 & 100,0 \\
\hline Total & 6 & 15,0 & 34 & 85,0 & 40 & 100,0 \\
\hline
\end{tabular}

Berdasarkan tabel 7 didapatkan hasil dari 7 orang yang memiliki tekanan darah tinggi, sebanyak 1 orang $(14,3 \%)$ dengan hasil kadar asam urat tinggi dan 6 orang $(85,7 \%)$ dengan hasil kadar asam urat normal. Dari 26 orang yang memiliki tekanan darah normal, sebanyak 4 orang $(15,4 \%)$ dengan hasil kadar asam urat tinggi dan 22 orang $(84,6 \%)$ dengan hasil kadar asam urat normal. Sedangkan dari 7 orang yang memiliki tekanan darah rendah, sebanyak 1 orang $(14,3 \%)$ dengan hasil kadar asam urat tinggi dan 6 orang $(85,7 \%)$ dengan hasil kadar asam urat normal.

Tabel 8. Distribusi Frekuensi Kadar Asam Urat pada Pekerja Bengkel Las Berdasarkan Asupan Purin

\begin{tabular}{|c|c|c|c|c|c|c|}
\hline \multirow{3}{*}{$\begin{array}{c}\text { Asupan } \\
\text { Purin }\end{array}$} & \multicolumn{4}{|c|}{ Kadar Asam Urat } & \multirow{2}{*}{\multicolumn{2}{|c|}{ Total }} \\
\hline & \multicolumn{2}{|c|}{ Tinggi } & \multicolumn{2}{|c|}{ Normal } & & \\
\hline & $\mathbf{n}$ & $\%$ & $\mathbf{n}$ & $\%$ & $\mathbf{N}$ & $\%$ \\
\hline Tinggi & 3 & 25,0 & 9 & 75,0 & 12 & 100,0 \\
\hline Sedang & 3 & 13,6 & 19 & 86,4 & 22 & 100,0 \\
\hline Rendah & 0 & 0,0 & 6 & 100,0 & 6 & 100,0 \\
\hline Total & 6 & 15,0 & 34 & 85,0 & 40 & 100,0 \\
\hline
\end{tabular}

Berdasarkan tabel 8 didapatkan hasil dari 12 orang yang memiliki asupan purin tinggi, sebanyak 3 orang $(25,0 \%)$ dengan hasil kadar asam urat tinggi dan 9 orang $(75,0 \%)$ dengan hasil kadar asam urat normal. Dari 22 orang yang memiliki asupan purin sedang, sebanyak 3 orang $(13,6 \%)$ dengan hasil kadar asam urat tinggi dan 19 orang $(86,4 \%)$ dengan hasil kadar asam urat normal. Sedangkan dari 6 orang yang memiliki asupan purin rendah, semuanya $(100,0 \%)$ dengan hasil kadar asam urat normal.

\section{Pembahasan}

Berdasarkan penelitian yang telah dilakukan pada pekerja bengkel las di Kecamatan Sukarami Palembang dapat diketahui dari tabel 4.1 bahwa dari 40 pekerja bengkel las didapatkan rata-rata kadar asam urat yaitu $5,88 \mathrm{mg} / \mathrm{dl}$ dengan kadar asam urat terendah yaitu $3,53 \mathrm{mg} / \mathrm{dl}$ dan kadar asam urat tertinggi yaitu 7,74 mg/dl. Dapat diketahui dari tabel 2 bahwa sebanyak 6 orang $(15,0 \%)$ dengan hasil kadar asam urat tinggi dan 34 orang $(85,0 \%)$ dengan hasil kadar asam urat normal. Penelitian ini lebih rendah hasilnya dengan penelitian lain yang menyatakan bahwa dari 1.235 orang yang terpapar kadmium ada 291 orang $(23,56 \%)$ dengan hasil kadar asam urat tinggi dan 944 orang $(76,44 \%)$ dengan hasil kadar asam urat normalm (Sun et al., 2017)

Peningkatan kadar asam urat pada pekerja bengkel las bisa terjadi karena penghirupan debu kadmium dari proses pengelasan dapat menyebabkan kerusakan ginjal. Kerusakan ginjal oleh kadmium dimulai dari cederanya tubulus ginjal proksimal yang dapat menyebabkan sekresi urat menurun dari sel tubulus. Toksisitas kadmium dapat menyebabkan gangguan ekskresi paminohidetik karena hilangnya pembawa anion organik pada membran basolateral tubulus proksimal. Disfungsi ini juga menyebabkan suatu bentuk arthritis akibat akumulasi kristal asam urat di persendian karena tingginya tingkat keasaman darah (hiperurisemia). Hal inilah yang menyebabkan terjadinya peningkatan kadar asam urat pada pekerja bengkel las (Sun et al., 2017).

Selain itu peningkatan kadar asam urat dapat terjadi karena adanya kelainan metabolik sehingga sintesis asam urat menjadi berlebihan, dapat juga disebabkan oleh faktor-faktor lain seperti tingginya asupan purin, obesitas, hipertensi, kelainan ginjal, obat-obatan tertentu (Utami \& Lentera, 2005).

Data pada tabel 3 menunjukkan dari 6 orang yang memiliki umur berisiko (>40 tahun), sebanyak 3 orang $(50,0 \%)$ dengan hasil kadar asam urat tinggi dan 3 orang $(50,0 \%)$ dengan hasil kadar asam urat normal. Sedangkan dari 34 orang yang memiliki umur tidak berisiko ( $\$ 40$ tahun), sebanyak 3 orang $(8,8 \%)$ dengan hasil kadar asam urat tinggi dan 31 orang $(91,2 \%)$ dengan hasil kadar asam urat normal. Penelitian ini lebih rendah hasilnya dengan penelitian lain yang menyatakan bahwa responden yang berumur $>40$ tahun lebih 
banyak yang memiliki kadar asam urat darah yang tinggi yaitu sebanyak 132 responden $(69,8 \%)$ dibandingkan dengan responden yang berumur $\$ 40$ tahun yaitu 57 responden $(30,2 \%)$ (Lioso et al., 2016).

Umur pekerja sangat diperhatikan karena dapat mempengaruhi fisik, mental, kemampuan kerja, dan tanggung jawab pekerja. Usia >40 tahun berisiko besar terkena asam urat karena terjadinya proses penyimpangan metabolisme (Damayanti, 2012). Sedangkan $3(8,8 \%)$ orang dengan umur tidak berisiko ( $\$ 40$ tahun) memiliki kadar asam urat yang tinggi bisa disebabkan karena masa kerja $>10$ tahun, tidak menggunakan APD, kebiasaan merokok dan bekerja $>8$ jam per hari.

Data tabel.4 didapatkan hasil dari 4 orang yang memiliki waktu kerja berisiko ( $>8$ jam), sebanyak 1 orang $(25,0 \%)$ dengan hasil kadar asam urat tinggi dan 3 orang $(75,0 \%)$ dengan hasil kadar asam urat normal. Sedangkan dari 36 orang yang memiliki waktu kerja tidak berisiko ( $\$ 8$ jam), sebanyak 5 orang $(13,9 \%)$ dengan hasil kadar asam urat tinggi dan 31 orang $(86,1 \%)$ dengan hasil kadar asam urat normal.

Penelitian ini lebih tinggi hasilnya dengan penelitian lain yang menyatakan bahwa pekerja bengkel las yang mempunyai waktu kerja $>8$ jam sebanyak $15,8 \%$ dengan hasil proteinuria positif dan $84,2 \%$ dengan hasil proteinuria negatif. Sedangkan pekerja bengkel las yang mempunyai waktu kerja $\$ 8$ jam sebanyak $14,8 \%$ dengan hasil proteinuria positif dan $85,2 \%$ dengan hasil proteinuria negatif (Imron, 2017).

Waktu kerja merupakan lamanya seorang pekerja bekerja satu hari dalam hitungan jam. Seorang pekerja tidak mampu dibebani lebih dari $30 \%$ dari tenaga maksimumnya selama 8 jam sehari (Prawidhana \& Prabowo, 2015). Semakin lama pekerja terpapar oleh paparan asap pengelasan akan semakin memperbesar risiko terjadinya gangguan kesehatan. Jumlah jam kerja seseorang mengakibatkan berbedanya intensitas pajanan dan banyaknya debu yang terhirup oleh masing-masing pekerja bengkel las, sehingga pekerja bengkel las yang cukup lama terlibat dalam aktivitas pekerjaannya berpotensi menghirup debu lebih banyak jika dibandingkan dengan pekerja bengkel las yang tidak lama terlibat dalam aktivitas pekerjaannya (Putra, 2014).

Data tabel 5 menunjukkan dari 10 orang yang memiliki masa kerja $\geq 10$ tahun, sebanyak 4 orang $(40,0 \%)$ dengan hasil kadar asam urat tinggi dan 6 orang $(60,0 \%)$ dengan hasil kadar asam urat normal. Sedangkan dari 36 orang yang memiliki masa kerja $<10$ tahun, sebanyak 2 orang $(6,7 \%)$ dengan hasil kadar asam urat tinggi dan 28 orang $(93,3 \%)$ dengan hasil kadar asam urat normal. Penelitian ini tidak sejalan dengan penelitian sebelumnya yang menyatakan bahwa tidak ada hubungan antara masa kerja dengan kadar ureum dan kreatinin pada pekerja bengkel las (Sugiharto et al., 2016).

Masa kerja merupakan suatu kurun waktu dan lamanya tenaga kerja bekerja di suatu tempat dan lama kontak dengan asap kadmium dari proses pengelasan dalam hitungan tahun. Paparan kadmium secara terus menerus akan terakumulasi pada ginjal. Waktu paruh kadmium adalah 10 tahun (Winata, 2017). Dilihat berdasarkan waktu paruh kadmium dalam tubuh, seseorang yang telah terpapar selama 10 tahun atau lebih akan terkena efek toksisitas kadmium. Salah satu efek toksisitas kadmium terhadap ginjal yaitu menyebabkan kerusakan ginjal yang dapat mengakibatkan defek ekskresi urat dan menimbulkan hiperurisemia (kadar asam urat tinggi). Hal ini disebabkan karena cederanya tubulus ginjal proksimal yang disebabkan karena keracunan kadmium sehingga menyebabkan sekresi urat menurun dari sel tubulus. Toksisitas kadmium dapat menyebabkan gangguan ekskresi paminohidetik karena hilangnya pembawa anion organik pada membran basolateral tubulus proksimal (Sun et al., 2017).

Berdasarkan hasil penelitian yang telah dilakukan, dari 4 orang $(40,0 \%)$ pekerja bengkel las dengan masa kerja berisiko $(\geq 10$ tahun) memiliki hasil kadar asam urat tinggi, 2 di antara 4 orang memiliki kebiasaan merokok $>10$ batang per hari dan tidak sesuai dalam penggunaan alat pelindung diri saat bekerja. Merokok juga menjadi salah satu faktor yang dapat mempengaruhi kadar asam urat pada pekerja bengkel las karena kandungan toksik dalam rokok juga terdapat banyak kadmium. Semakin lama seseorang bekerja pada proses pengelasan yang mengakibatkan risiko terpapar kadmium dan disertai dengan kebiasaan merokok, maka semakin besar efek toksik yang didapat. Selain itu, penggunaan alat pelindung diri juga saat penting untuk mengurangi paparan secara langsung dari proses pengelasan. Sedangkan 2 orang $(6,7 \%)$ pekerja bengkel las dengan masa kerja tidak berisiko ( $<10$ tahun) memiliki hasil kadar asam urat tinggi. Keduanya tidak memiliki kebiasaan merokok, 1 di antara 2 orang tidak sesuai dalam 
penggunaan alat pelindung diri, namun keduanya memiliki asupan purin yang tinggi. Hal inilah yang sangat berpengaruh dalam peningkatan kadar asam urat karena apabila seseorang mengkonsumsi makanan yang mengandung purin, maka purin akan langsung dikatabolisme oleh usus.

Data tabel 6 didapatkan hasil dari 21 orang yang tidak sesuai dalam penggunaan APD, sebanyak 5 orang $(23,8 \%)$ dengan hasil kadar asam urat tinggi dan 16 orang $(60,0 \%)$ dengan hasil kadar asam urat normal. Sedangkan dari 19 orang yang sesuai dalam penggunaan APD, sebanyak 1 orang $(5,3 \%)$ dengan hasil kadar asam urat tinggi dan 18 orang $(94,7 \%)$ dengan hasil kadar asam urat normal.

Alat pelindung diri ini berfungsi untuk menghindari paparan langsung dari proses pengelasan, diantaranya menghindari terhirupnya kadmium atau tidak sengaja masuk lewat mulut saat bekerja, menghindari masuknya kadmium ke tubuh melalui udara, mulut, atau luka injeksi pada kulit. Karena apabila kadmium dalam tubuh berada dalam dosis yang toksik akan menyebabkan berbagai kerusakan hati, ginjal, empisema, impotensi, bahkan kerapuhan tulang (Yusuf, 2013).

Berdasarkan hasil penelitian yang telah dilakukan, terdapat 1 orang $(5,3 \%)$ yang sesuai dalam penggunaan APD memiliki kadar asam urat tinggi. Hal ini bisa disebabkan karena ia memiliki tekanan darah tinggi dan mengkonsumsi makanan yang memiliki asupan purin tinggi.

Data Tabel 7 didapatkan hasil dari 7 orang yang memiliki tekanan darah tinggi, sebanyak 1 orang $(14,3 \%)$ dengan hasil kadar asam urat tinggi dan 6 orang $(85,7 \%)$ dengan hasil kadar asam urat normal. Dari 26 orang yang memiliki tekanan darah normal, sebanyak 4 orang $(15,4 \%)$ dengan hasil kadar asam urat tinggi dan 22 orang $(84,6 \%)$ dengan hasil kadar asam urat normal. Sedangkan dari 7 orang yang memiliki tekanan darah rendah, sebanyak 1 orang $(14,3 \%)$ dengan hasil kadar asam urat tinggi dan 6 orang $(85,7 \%)$ dengan hasil kadar asam urat normal.

Penelitian ini sejalan dengan penelitian sebelumnya yang menyatakan bahwa responden yang terpapar kadmium $>0,005 \% \mathrm{mg} / \mathrm{l}$ terdapat $36,5 \%$ dengan hasil tekanan darah tinggi dan $63,5 \%$ dengan hasil tekanan darah normal. Sedangkan responden yang terpapar kadmium $\$ 0,005 \mathrm{mg} / \mathrm{l}$ terdapat $39,4 \%$ dengan hasil tekanan darah tinggi dan $60,6 \%$ dengan hasil tekanan darah normal. Hal ini menunjukkan bahwa responden yang terpapar kadmium $>0,005 \mathrm{mg} / \mathrm{l}$ memiliki peluang terkena hipertensi (1,079 kali lebih besar) dibandingkan responden yang terpapar kadmium $₫ 0,005 \mathrm{mg} / \mathrm{l}$ (Irsan, 2016).

Selain itu, penelitian ini juga sejalan dengan penelitian lain yang menyatakan bahwa responden yang memiliki rata-rata kadar kadmium dalam darah sebesar 2,40 mikrogram/L dan positif hiperurisemia, memiliki persentase hipertensi sebesar $47,8 \%$, sedangkan responden yang memiliki rata-rata kadar kadmium dalam darah sebesar 1,98 mikrogram/L dan negatif hiperurisemia, memiliki persentase hipertensi sebesar $36,4 \%$ (Sun et al., 2017).

Penyakit asam urat berkaitan dengan tekanan darah tinggi. Penyakit asam urat merupakan penyakit radang sendi akibat penumpukan asam urat dalam darah sehingga membentuk kristal-kristal di area sendi dan pembuluh darah kapiler. Ketika terjadi pergerakan, kristal asam urat akan tertekan dan menusuk dinding pembuluh darah kapiler dan menghambat aliran darah sehingga menyebabkan peningkatan tekanan darah. Selain itu, berdasarkan penelitian yang dilakukan oleh Umami (2015) menyatakan bahwa orang yang mengalami hiperurisemia (peningkatan kadar asam urat dalam darah) lebih berisiko mengalami hipertensi dibandingkan dengan orang yang memiliki kadar asam urat normal (Medika, 2017).

Berdasarkan hasil penelitian yang telah dilakukan, terdapat 4 orang $(15,4 \%)$ dengan tekanan darah normal yang memiliki kadar asam urat tinggi. Hal ini dapat disebabkan karena 2 di antara 4 orang mengkonsumsi makanan dengan asupan purin tinggi, 1 di antara 4 orang memiliki waktu kerja berisiko, 2 di antara 4 orang memiliki umur berisiko, dan 3 di antara 4 orang tidak sesuai dalam penggunaan APD dan masa kerja berisiko. Selain itu, terdapat 1 orang $(14,3 \%)$ dengan tekanan darah rendah yang memiliki kadar asam urat tinggi. Hal ini dapat disebabkan karena ia memiliki masa kerja berisiko dan tidak sesuai dalam penggunaan APD.

Data tabel 8 didapatkan hasil dari 12 orang yang memiliki asupan purin tinggi, sebanyak 3 orang $(25,0 \%)$ dengan hasil kadar asam urat tinggi dan 9 orang $(75,0 \%)$ dengan hasil kadar asam urat normal. Dari 22 orang yang memiliki asupan purin sedang, sebanyak 3 orang $(13,6 \%)$ dengan hasil kadar asam urat tinggi dan 19 orang $(86,4 \%)$ dengan hasil kadar asam urat normal. Sedangkan dari 6 orang yang 
memiliki asupan purin rendah, sebanyak 0 orang $(0,0 \%)$ dengan hasil kadar asam urat tinggi dan 6 orang $(100,0 \%)$ dengan hasil kadar asam urat normal.

Penelitian ini lebih rendah hasilnya dengan penelitian lain yang menyatakan bahwa dari 88 responden yang memiliki pola konsumsi purin yang berisiko, sebagian besar yakni 49 responden $(80,3 \%)$ yang menderita asam urat. Sedangkan dari 34 responden yang memiliki pola konsumsi purin yang tidak berisiko, sebesar 22 responden $(36,1 \%)$ tidak menderita asam urat (Jaliana \& Suhadi, 2018).

Kadar asam urat di dalam darah dapat dipengaruhi oleh asupan purin tinggi yang didapat dari makanan. Asam urat sendiri merupakan hasil metabolisme dari purin. Tubuh manusia sebenarnya telah mengandung purin sebesar $85 \%$ sehingga purin yang boleh didapat dari luar tubuh (dari makanan) hanya sebesar 15\% (Medika, 2017). Purin termasuk komponen non-esensial bagi tubuh, artinya purin dapat diproduksi oleh tubuh sendiri. Apabila seseorang mengkonsumsi makanan yang mengandung purin, maka purin akan langsung dikatabolisme oleh usus (Damayanti, 2012). Hal inilah yang dapat mempengaruhi kadar asam urat yang meningkat bisa disebabkan karena efek toksik dari kadmium atau asupan purin yang tinggi.

Berdasarkan hasil penelitian yang telah dilakukan, terdapat 3 orang $(13,6 \%)$ dengan asupan purin sedang yang memiliki kadar asam urat yang tinggi. Hal ini dapat disebabkan karena ketiganya tidak sesuai dalam penggunaan APD dan memiliki masa kerja berisiko, 2 di antara 3 orang memiliki kebiasaan merokok, 1 di antara 3 orang memiliki waktu kerja berisiko dan 1 di antara 3 orang memiliki umur berisiko.

Simpulan hasil penelitian ini adalah:

1. Dari 40 pekerja bengkel las yang diperiksa, didapatkan sebanyak 6 orang $(15,0 \%)$ mengalami kadar asam urat tinggi dan 34 orang $(85,0 \%)$ mengalami kadar asam urat normal.

2. Berdasarkan umur, dari 6 orang dengan umur berisiko (>40 tahun) sebanyak 3 orang $(50 \%)$ memiliki kadar asam urat tinggi dan 3 orang (50\%) memiliki kadar asam urat normal. Sedangkan dari 34 orang dengan umur tidak berisiko ( $\$ 40$ tahun) sebanyak 3 orang $(8,8 \%)$ memiliki kadar asam urat tinggi dan 31 orang $(91,2 \%)$ memiliki kadar asam urat normal.

3. Berdasarkan waktu kerja, dari 4 orang dengan waktu kerja berisiko (>8 jam) sebanyak 1 orang $(25,0 \%)$ memiliki kadar asam urat tinggi dan 3 orang $(75,0 \%)$ memiliki kadar asam urat normal. Sedangkan dari 36 orang dengan waktu kerja tidak berisiko ( $\$ 8$ jam) sebanyak 5 orang $(13,9 \%)$ memiliki kadar asam urat tinggi dan 31 orang $(86,1 \%)$ memiliki kadar asam urat normal.

4. Berdasarkan masa kerja, dari 10 orang dengan masa kerja berisiko ( $\geq 10$ tahun) sebanyak 4 orang $(40,0 \%)$ memiliki kadar asam urat tinggi dan 6 orang $(60,0 \%)$ memiliki kadar asam urat normal. Sedangkan dari 36 orang dengan masa kerja tidak berisiko ( $<10$ tahun) sebanyak 2 orang $(6,7 \%)$ memiliki kadar asam urat tinggi dan 28 orang $(93,3 \%)$ memiliki kadar asam urat normal.

5. Berdasarkan penggunaan APD, dari 21 orang yang tidak sesuai dalam penggunaan APD, sebanyak 5 orang $(23,8 \%)$ memiliki kadar asam urat tinggi dan 16 orang $(60,0 \%)$ memiliki kadar asam urat normal. Sedangkan dari 19 orang yang sesuai dalam penggunaan APD, sebanyak 1 orang $(5,3 \%)$ memiliki kadar asam urat tinggi dan 18 orang $(94,7 \%)$ memiliki kadar asam urat normal.

6. Berdasarkan tekanan darah, dari 7 orang dengan tekanan darah tinggi sebanyak 1 orang $(14,3 \%)$ memiliki kadar asam urat tinggi dan 6 orang $(85,7 \%)$ memiliki kadar asam urat normal. Dari 26 orang dengan tekanan darah normal sebanyak 4 orang $(15,4 \%)$ memiliki kadar asam urat tinggi dan 22 orang $(84,6 \%)$ memiliki kadar asam urat normal. Sedangkan dari 7 orang dengan tekanan darah rendah sebanyak 1 orang $(14,3 \%)$ memiliki kadar asam urat tinggi dan 6 orang $(85,7 \%)$ memiliki kadar asam urat normal.

7. Berdasarkan asupan purin, dari 12 orang dengan asupan purin tinggi ditemukan sebanyak 3 orang $(25,0 \%)$ memiliki kadar asam urat tinggi dan 9 orang $(75,0 \%)$ memiliki kadar asam urat normal. Dari 22 orang dengan asupan purin sedang ditemukan sebanyak 3 orang $(13,6 \%)$ memiliki kadar asam urat tinggi dan 19 orang $(86,4 \%)$ memiliki kadar asam urat normal. Sedangkan dari 6 orang dengan asupan purin rendah ditemukan sebanyak 0 orang $(0,0 \%)$ memiliki kadar asam urat tinggi dan 6 orang $(100,0 \%)$ memiliki kadar asam urat normal.

Saran yang dapat diberikan yaitu pekerja bengkel las agar menggunakan APD yang 
sesuai, untuk mengurangi paparan asap yang mengandung kadmium. Pekerja bengkel las sebaiknya secara berkala melakukan pemeriksaan darah untuk deteksi dini adanya penyakit yang berhubungan dengan kadmium.

\section{Daftar Pustaka}

Åkesson, A., Barregard, L., Bergdahl, I. A., Nordberg, G. F., Nordberg, M., \& Skerfving, S. (2014). Non-renal effects and the risk assessment of environmental cadmium exposure. Environmental health perspectives, 122(5), 431-438.

Damayanti, D. (2012). Panduan lengkap mencegah \& mengobati asam urat. Yogyakarta: Araska.

Fitriadi, R. (2009). Penentuan Prioritas Alternatif Pengelasan Pada Body Welding Minibus.

Hashmi, S. (2014). Comprehensive materials processing: Newnes.

Imron , M. (2017). Gambaran Proteinuria pada Pekerja Bengkel Las di Pasar Cinde Kecamatan 24 Ilir Palembang Tahun 2017. . Karya Tulis Ilmiah.

Indonesia, K. K. R. (2012). Penyakit Akibat Kerja Karena Pajanan Logam Berat: Direktorat Bina Kesehatan Kerja dan Olahraga Kementerian Kesehatan Republik ....

Irsan, P. R. (2016). Hubungan Kadar Kadmium (Cd) Pada Air Sumur Dengan Tekanan Darah Masyarakat di Desa Namo Bintang Kabupaten Deli Serdang Tahun 2016.

Jaliana, J., \& Suhadi, S. (2018). faktor-faktor yang berhubungan dengan kejadian asam urat pada usia 20-44 tahun di RSUD Bahteramas Provinsi Sulawesi Tenggara tahun 2017. Jurnal Ilmiah Mahasiswa Kesehatan Masyarakat, 3(2).

Lioso, J. P., Sondakh, R. C., \& Ratag, B. T. (2016). Hubungan Antara Umur, Jenis Kelamin Dan Indeks Massa Tubuh Dengan Kadar Asam Urat Darah Pada Masyarakat Yang Datang Berkunjung Di Puskesmas Paniki Bawah Kota Manado.

Medika, T. B. (2017). Berdamai Dengan Asam Urat: Bumi Medika: Jakarta.

Permatasari, G., Setiadi, G., \& Arifin, A. (2017). Hubungan Pengetahuan, Sikap dan Kenyamanan Pekerja dengan Pemakaian Alat Pelindung Diri (APD) di Bengkel Las Listrik Kecamatan Amuntai Tengah Kabupaten HSU Tahun 2016. JURNAL KESEHATAN LINGKUNGAN:
Jurnal dan Aplikasi Teknik Kesehatan Lingkungan, 14(1), 383-390.

Prawidhana, W. A., \& Prabowo, S. (2015). Pengaruh Musik terhadap Kelelahan Kerja. PSIKODIMENSIA, 14(2), 9-17.

Putra, N. D. (2014). Faktor-Faktor yang Berhubungan dengan Kapasitas Vital Paru pada Pekerja Bengkel Las di Kelurahan Cirendeu, Tahun 2014.

Putri, A. D., \& Setiawina, D. (2013). Pengaruh umur, pendidikan, pekerjaan terhadap pendapatan rumah tangga miskin di Desa Bebandem. E-Jurnal Ekonomi Pembangunan Universitas Udayana, 2(4).

RI, K. K. (2015). Situasi kesehatan kerja. Jakarta: Kemenkes RI.

Rorimpandey, M. (2014). Hubungan Antara Pengetahuan Dan Sikap Dengan Tindakan Penggunaan Alat Pelindung Diri Pada Pekerja Pengelasan Di Bengkel Las Kota Manado. Manado: Fakultas Kesehatan Masyarakat Universitas Sam Ratulangi.

Sembel, D. T. (2015). Toksikologi lingkungan: Penerbit Andi.

Sugiharto, S. B., Suwarso, S., \& Prawirohardjono, W. (2016). Level kadmium darah dan fungsi ginjal ditinjau dari kadar ureum dan kreatinin pekerja las bengkel knalpot di Purbalingga. Berita Kedokteran Masyarakat, 32(4), 119-124.

Sun, H., Wang, N., Chen, C., Nie, X., Han, B., Li, Q., . . . Chen, Y. (2017). Cadmium exposure and its association with serum uric acid and hyperuricemia. Scientific reports, $7(1), 550$.

Utami, P., \& Lentera, T. (2005). Tanaman obat untuk mengatasi rematik dan asam urat. Jakarta: Agromedia Pustaka, 57-58. (pustaka 10 tahun terakhir)

Winata, S. D. (2017). Monitoring, Pencegahan, dan Penanganan Keracunan pada Pekerja Terpapar Cadmium. Jurnal Kedokteran Meditek, 22(59).

Yusuf, A. (2013). Aspek Kesehatan dan Keselamatan Kerja (K3) pada Pekerja yang Terpapar Kadmium di Bengkel Las dan Konstruksi Besi Surya Teknik Makassar. 